\title{
Contribution of a CRM System to the Creation of a Family-Friendly Working Environment
}

\author{
Andrea Tick ${ }^{1}$, Gyöngyi Szabó ${ }^{2}$, Regina Zs. Reicher ${ }^{3}$ \\ ${ }^{1}$ Óbuda University, Bécsi út 96/b, 1034 Budapest, Hungary, \\ tick.andrea@uni-obuda.hu \\ ${ }^{2}$ Óbuda University, Doctoral School on Safety and Security Sciences, \\ Bécsi út 96/b, 1034 Budapest, Hungary, szabo.gyongyi@ stud.uni-obuda.hu \\ ${ }^{3}$ Óbuda University, Bécsi út 96/b, 1034 Budapest, Hungary, \\ reicher.regina@uni-obuda.hu
}

\begin{abstract}
Today's pandemic situation intensifies companies' competition for customers. The rapid acceleration and growth of economic competition, is a serious challenge to meet, for many companies. With the wide range of market supply and the resulting increase in price competition, customers are increasingly switching brands or service providers, with the result, that it is much more difficult for businesses to retain customers. The peculiarities of this situation are a strong customer focus, the possibility to expand direct communication with the customer and the seemingly endless range of products and services offered [1]. Managers focusing on maintaining and improving the competitiveness of companies, are paying increasing attention to meeting special needs, getting to know different segments of the market and more effective marketing communication with customers. Efforts in this direction, by all business organizations, including family-friendly businesses, are also supported by CRM (Customer Relationship Management) systems that - when they work well - results in a long-term, difficult to imitate competitive advantage, in addition to the already existing family-friendly policy, within a company. The current research aims to explore employee needs, for a family-friendly workplace. The focus of this study is on corporate services and expectations, as well as, on their evaluation and acceptance by the employees. This paper is based on a two-step research approach; while the secondary study investigates the related literature, in the framework of the primary research, a case study is presented.
\end{abstract}

Keywords: CRM system; family-friendly company; relationship marketing; corporate strategy 


\section{Family-Friendly Companies}

One of the most frequently choices, in our everyday lives, is "family" or "career". With the words by Ternovszky, "Income is not the main basis for happiness; family and work are more important. A family is that which provides love, affection, security, recognition and care. The joy of working, the stimulation that comes from it and the joy of action through the self-confidence that comes with it", so the answer is that the two must be able to work together, in the life of families [2].

In the $21^{\text {st }}$ Century the image of women in the labor market is not the same as it was in the previous decades. Nowadays, a very tight lifestyle has come to the fore in the life of woman compared to the earlier, weaker, and family-focused image. They are appearing in increasing numbers as employees, with the number of twoearner families growing across Europe [3]. As a result, reconciling work and private life has become a basic need [4].

"Family-friendly" as a concept has become known in Hungary as a support for the weaker sex, in everyday life, but it must be emphasized that this is much more than that. It includes, inter alia, also, that women and men in family life can and are able to take part in the most optimal way. In this more and a more equitable distribution of tasks, in the labor market discrimination against women might decrease, as the employer sees that child upbringing and problems occurring in a household, are divided between men and women and, therefore, not only women shy away from work [5]. The organizational appearance of these details is the family-friendly workplace.

Family-friendly workplaces help to create a work-life balance by providing their employees with the opportunity to reconcile family life and work as finely as possible [6]. Table 1 shows work-life balance options for gender and ageindependent sitting.

From the column of allowances and services, the provision of childcare is highlighted as one of the main areas in this paper. The employer may decide to create a service for the child of an employee who is gainfully employed by him, in which he undertakes to supervise the child, thus relieving the workforce. This is not a nursery school or a kindergarten operating within the institutional framework, but usually in a building located at the company's headquarters and premises, where the number of specialists caring for children in accordance with the regulations is provided.

Győrpál et al. state in their publication "the positive example presented as a good practice also proves that the integration and application of family-friendly HR policy into the life of a company is of paramount importance. It has an impact not only on the better advancement of women in the world of work and the results of a company, but also on society, the economy and social well-being. To do all this, 
however, it is essential to develop a new supportive value system, approach and culture that treats the reconciliation of childbearing and careers as a value that supports the advancement of working women with families. And in the long run, it is essential to incorporate and manage this as part of the corporate strategy" [7].

Table 1

Work Life Balance Tools for Companies [8, p. 11]

\begin{tabular}{|c|c|}
\hline \multicolumn{2}{|c|}{ WLB tools that can be applied by companies } \\
\hline Related to worktime & Related to work completion \\
\hline $\begin{array}{l}\text { - Flexible starting and ending times } \\
\text { - Flexible working time } \\
\text { - Working time bank } \\
\text { - Shortened working week } \\
\text { - Shortened working time } \\
\text { - Reduction of overtime } \\
\text { - Part-time employment } \\
\text { - Working year equaling school year } \\
\text { - Voluntary worktime scheduling } \\
\text { - (Self-rostering) }\end{array}$ & $\begin{array}{l}\text { - Home office } \\
\text { - Job sharing } \\
\text { - Casual, temporary job } \\
\text { - Remote working } \\
\text { - Multiple shifts, shift changing }\end{array}$ \\
\hline Off work/holiday procedures & Allowances and services \\
\hline $\begin{array}{l}\text { - Lengthening of maternity leave } \\
\text { - Home office } \\
\text { - Job sharing } \\
\text { - Casual, temporary job } \\
\text { - Remote working } \\
\text { - Multiple shifts, shift changing } \\
\text { - Maternity leave for fathers (paternity } \\
\text { - leave) } \\
\text { - Exildcare allowances (to fathers as well) } \\
\text { - Family holidays } \\
\text { - Career off work time } \\
\text { - Sabbatical }\end{array}$ & $\begin{array}{l}\text { - Services for pregnant women } \\
\text { - Child supervision } \\
\text { - Allowances to other dependents/cared } \\
\text { - Education } \\
\text { - Panels, consultancy } \\
\text { - Shopping, cleaning within blocks of flats } \\
\text { - sport facilities } \\
\text { - "Personal life assistant", coaching } \\
\text { - Charity work, TCR } \\
\text { - Supportive programs } \\
\text { - Medical care } \\
\text { - "Confidence room" } \\
\text { - Chappel, right for religion practice }\end{array}$ \\
\hline
\end{tabular}

A family-friendly workplace, which already includes work-life balance policies in its corporate strategy, has many potential benefits for the market for economic operators. Family-friendly workplaces are also challenged by "coexistence at work" with those living in a mosaic family [5].

Family-friendly working conditions are mostly influenced by the in-house approach, but it is also shaped by the state's family policy. Intra-company regulation, which strives for work-life balance, is also an important factor for employees and employers [9]. In business life the introduction of this program 
leads to greater cost savings for employers [10] [11], since the unreasonably high costs of workforce recruiting do not burden the company's results [12], it contributes to the company's image, and last but not least, employee loyalty to the employer increases. The research by Wiß [13] also confirms that flexible working hours are one of the most important and effective elements of this specific policy for both internal and external stakeholders. Further research justifies that a wellorganized regulation achieves a double result. If employees have an optimal workfamily balance (welfare appears), then its effect is also reflected in the turnover of the company, therefore, a win-win situation develops [14] [15].

By providing day care for workers' children in the form of corporate crèches, nurseries or even temporary childcare, employers help employees to meet private and workplace needs in a coordinated way. This attitude results in an increase in workforce efficiency and loyalty towards the company. In fact, these familyfriendly provisions create such flexibility, supportive environment, that reduce the tension between work and family. Funds assigned to the "Family-friendly Award" help winners to establish nurseries or even kindergartens within the company, or these funds can be dedicated to tools and devices needed in the course of child supervision [8].

The economy of the $21^{\text {th }}$ Century is characterized by structural change, the emphasis is shifted from products to services, to which family-friendly workplaces must also adapt in order to retain their competitive position and existing customers. To support "family friendliness" the introduction of a Customer Relationship Manager (CRM) system can be excellent, which can not only be used to actively communicate with company customers and accurately assess their needs but can also actively participate in supporting employee management.

\subsection{State Measures}

In order to provide certain opportunities for employees during their active years, state organizations and governments have set minimum requirements for employees. Such minimum allowances, for example, typically offer either a replacement for childcare, such as a crèche, or a work schedule that provides flexibility in the timing and location of work, such as working from home. The purpose of such organizational supports is to help employees improve on the balance between work and time not spent by working [16].

A large-scale study examined the impact of work-based and non-work-related benefits on employee well-being. The result showed that the use of work-related and non-work-related benefits is indirectly linked to well-being through workplace control and supportive management. Evidence has also been found that increased workplace control, through the use of work and other support, allows workers to reduce work-life conflicts and achieve significant improvements in well-being [17]. 
The main policy implication of the results of the research by Wood et al. [17] for human resource management is that employment and non-employment subsidies should be accepted and, where appropriate, should be encouraged to be used. These are easy-to-implement tools by which an employer could - and visibly can - support working relationships, the needs of workers and can improve the support and control they experience. In addition, they contribute to the understanding of improving job characteristics and are thus in line with a more conscious design of jobs and a revitalization of the quality of work. The negative finding of the study that subsidies between work and non-work do not significantly reduce labor demand is also important to reinforce the argument that we need to place more emphasis on workplace control and their supportive effect, otherwise, there is a risk that the aid will be considered to be of little value on the grounds that it does not achieve its expected primary objective, which is to reduce conflicts between high labor standards and reducing conflicts between non-work needs [17].

\subsection{Corporate Challenges}

\subsubsection{Performance Evaluation}

The current practice for managers is to evaluate the performance, personality and behavior provided in the subordinate work. A paper or electronic form is usually available for this purpose. The evaluation seeks to determine the employee's level of aptitude, the need for further training and the use of possible reward opportunities. Nowadays, a strong change can be observed in this process [18]. The right system is also suitable for visualization. Good visualization should be such that decision makers are able to see the differences immediately and they are able to draw conclusions depending on the point of view [19].

Another very important benefit of a performance appraisal done with the right methodology is a satisfied employee. Employers try to develop a number of different evaluation-motivation systems in order for the employee to be satisfied with the results, method and recommendations of the evaluation, to accept it and to be able to integrate it into their daily practice.

This is also important because with the advent of the new type of employee, employers will have to face a large increase in fluctuation [20].

\subsubsection{New Type of Employee}

Countless research has been done on the new type of workers who have been entering the labor market for about 5-8 years. Generation Y members then began to represent themselves in larger numbers and employers were then confronted with the fact that new expectations, new forms of behavior could be attributed not to a person but rather to a generation, a very broad group of employees. 
Several researchers agree that communication between members of the new generations, such as the $\mathrm{Y}$ and $\mathrm{Z}$ generations, is very different from previous ones, and HR professionals and psychologists have repeatedly drawn employers' attention to the fact that this will be a serious concern both for employees and employers. A study conducted about Chinese graduates' communication problems at their first workplace named and highlighted these problems [21]. According to Machová et al. [22] generations $\mathrm{Y}$ and $\mathrm{Z}$ place emotional intelligence more important than cognitive intelligence. This plays an important role as it plays a crucial role in communication and in situations that affect behavior. The behavior of members of generations can differ in several areas, which can cause serious workplace tensions. They think differently about job opportunities, working hours, family, possible leisure time, fixed location and mobility. Numerous studies report that members of Generation Y change jobs on average 4 times more times over a specific period of time than workers in Generation X.

As a result, this fluctuation makes the everyday life of companies very difficult. This process can be a very serious cost factor in the life of a company, as the company invests in the workforce at the initial time and if the employee leaves within a short time, the energy invested does not pay off. In addition, more time, energy and money need to be sacrificed for the new workforce, from recruitment to training [23].

\section{The Potential of a CRM System}

In order to increase the competitiveness of companies, they are introducing more and more efficient and integrated processes for serving their customers and managing their relationships. For almost 30 years, CRM, i.e. customer relationship management, has been helping companies in this direction [24]. Customer Relationship Management is located in the relationship marketing sub-area within marketing. Relationship marketing focuses on making marketing in the traditional sense even more customer centric [25].

Like traditional marketing, relationship marketing rests on building blocks (Figure 1).

The first element is to deliver the right message by the business to its customers, followed by the targeting of the right customer in the second step. This is followed on the third level by finding the right time for the message to be delivered. The fourth element (via the right way) means developing the right method to convey the message, while finally the mediation, the information conveyed should always be relevant (at all times be relevant!) [26]. 


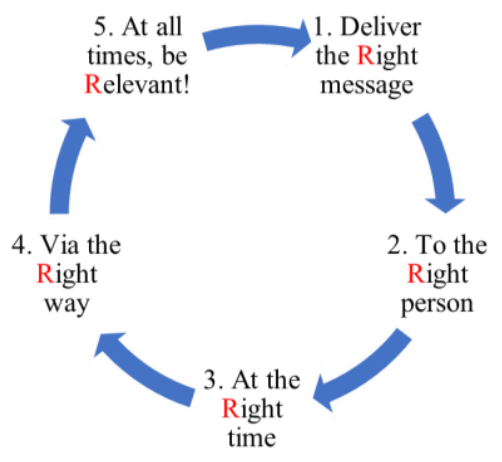

Figure 1

5Rs of relationship marketing

Source: edited by authors

The definition of CRM has undergone a paradigm shift compared to the initial definitions. In the most commonly used domestic and foreign interpretations, in contrast to the previous financial approach, CRM is already being raised to the level of corporate strategy, along with customer value and long-term relationships. Perhaps Payne and Frow's definition is the most complete in this regard: "CRM is such a strategic approach that seeks to increase shareholder value by building the right relationships with key customers and segments of a company. CRM combines relationship strategies with information technology to build long-term relationships with customers and other stakeholders" [27, p. 59]. Figure 2 well illustrates the strategic role of CRM, its connection points with the individual processes of the company.

Grönroos [28] also points out that this type of marketing activity focuses on the long-run relationship versus the price of the product or service. Part of this process is, among other things, building a relationship of trust with customers, as well as planning - which should already be reflected in the company's strategy.

The purpose of the performance appraisal process is, among other things, to ensure that the organization's strategic goals are met at the appropriate level in terms of CRM, and that the foundation for future developments is firmly established. This process focuses on how greater profits can be created, how standards can be determined and performance can be improved. These considerations allow companies to understand how CRM delivers shareholder results and how CRM performance can be measured and thereby can be further improved.

A new concept has emerged in the field of the CRM market and in the field of corporate strategy creation. Over the past 10 years, the growth seemed to be unlimited, and the supporting IT solutions were in the center of attention. 


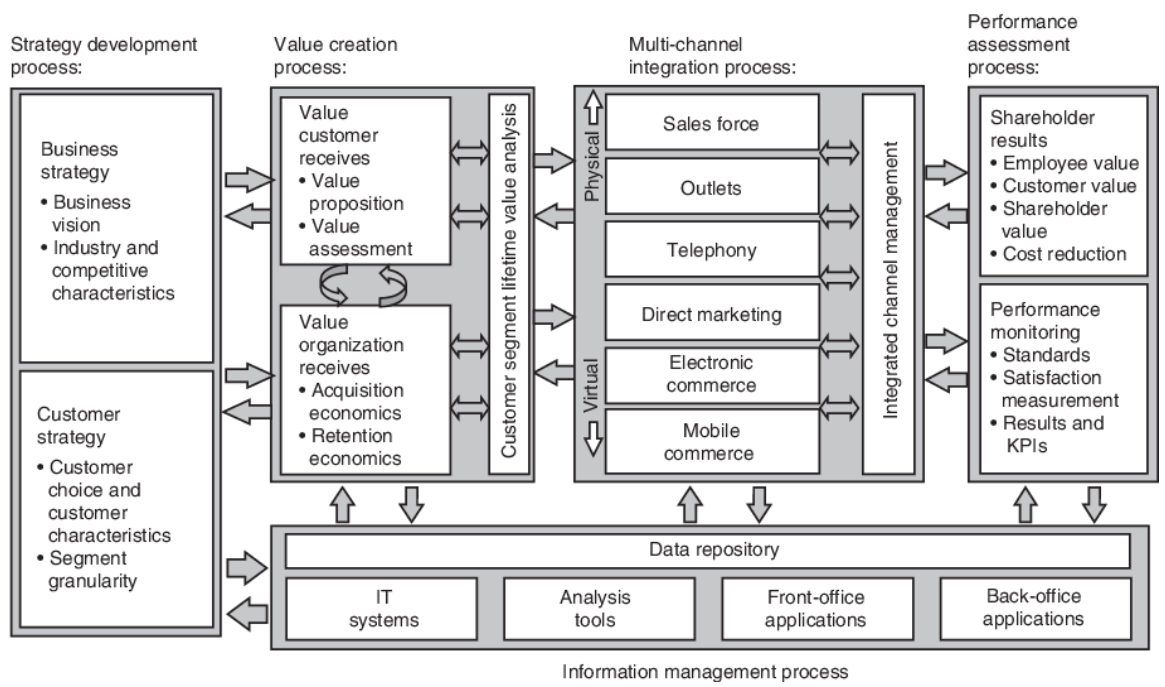

Figure 2

Strategic model of CRM [27, p. 59]

Nowadays, however, IT solutions, including CRM systems, are emerging as costsaving solutions. It is still in the business interest of companies to find the right consumer layer for their products and services, but they are increasingly thinking of solutions that enable better use of existing resources.

Along a proper CRM implementation and operational strategies greater organizational efficiency can be achieved, where the optimal cost management is more efficient, labor utilization kept in mind and thus significantly might increase the competitiveness of companies. A CRM system can support manufacturing process design and in addition to designing process it might be able to anticipate manufacturing resource needs and to effect workforce planning as well. In addition, it might evaluate production data, working hours and taking into account prescribed standards and norms; it might assess labor performance and efficiency of resource utilization.

If process-controlling role comes to the fore as a result of the introduction of CRM, process-based costing and performance indicators systems can form the basis for process controlling operation. The component of the existing information basis that can be found at the company such as CRM - customer relationship management data and measurements, such as customer satisfaction surveys, employee satisfaction levels, productivity measurement might serve as the input information of process-based costing and performance indicators. The most important performance indicators and information on resource use can be determined using this information basis. 
We also have the option of working time management support. For CRM tasks, the amount of planned and actual working time can be set directly, thus making it easier to plan the working time to be spent on each project. Every task completed can be recorded: this way efficiency broken down by day can be measured.

It can also support B2B relationships. All the events related to subcontractors can be accurately recorded in a CRM system. This also makes the work and performance of subcontractors accurately measurable.

The aim of a CRM is that with its use the company becomes capable to find what "value" means for its customers at purchasing a service or when using the product. Its basic element is the repetitive exchange activity, that is, this process has both an antecedent and a future [29]. With the spread of the Internet, the actors of the economy were given the opportunity to deliver their products and services to as many people as possible in a time- and cost-effective manner. The online interface ensures - not just for family-friendly companies - that they communicate with their customers and build relationships with their customers [30]. Consequently, business owners already need to include the planning, the implementation and, of course, the analysis of internet marketing campaigns in their company strategy [1]. All in all, it can be said that CRM supports the organization and management of customer relations of business organizations, which is based not only on the tools and software operating on the Internet interface but also on the company's strategy.

In the development of activities (research and development, investment) of SMEs - including family-friendly enterprises operating in the SME sector - grants that can be obtained through tenders play a major role. Funds for investments funded under the 2014-2020 EU budget period will enable SMEs to acquire new technology and innovation skills. In 2018 the most popular calls from businesses were related to the Operational Program for Economic Development and Innovation (GINOP), which accounted for $93 \%$ of all payments. [31]. With these grants, economic organizations can provide resources to procure such software that allow them to build long-term relationships with their customers. CRM systems running on the cloud base or on the company's internal network are excellent for this purpose. Cloud-based operations are more exposed to security risks because the Internet is the most widely used information retrieval interface in the world today [32]. While in 2017, Hungary's economic organizations are lagging compared to the average of the $E U(28)$ in the use of CRM systems (Figure 3) [33], market participants projected growth. However, the growth has not been achieved as shown in Figure 3. 


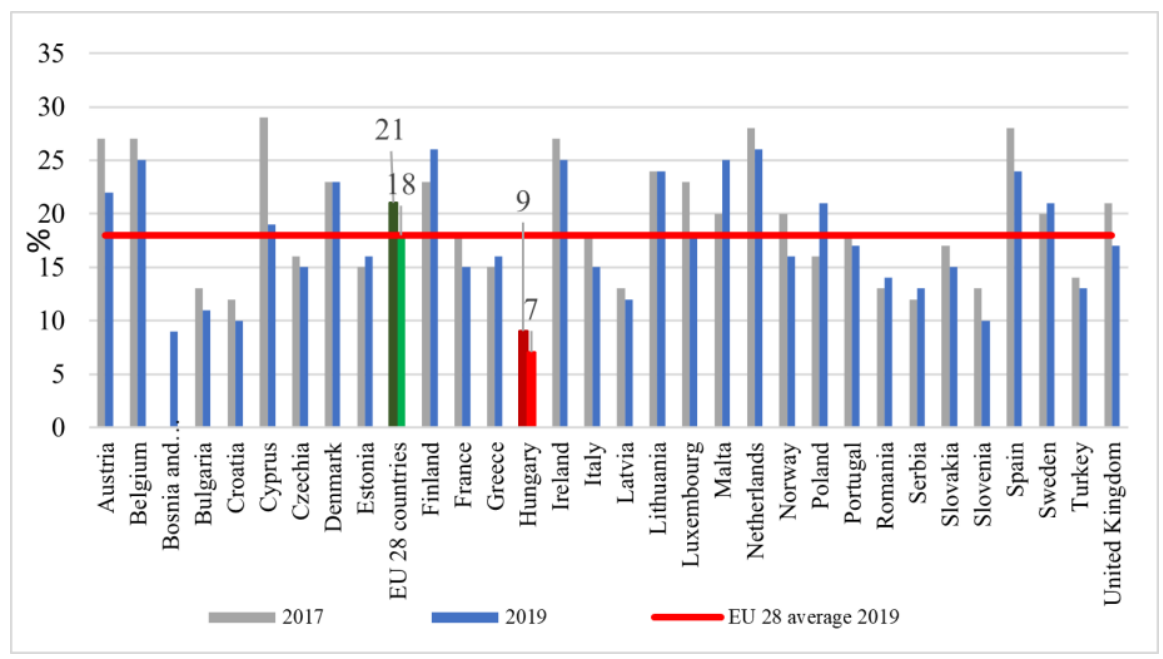

Figure 3

Ratio of business enterprises using software solutions such as CRM to analyze the information about their clients in 2017 and 2019 (\%) [33]

In Figure 3 the horizontal axis shows the countries, and the vertical axis displays the proportion of CRM usage within the countries. In a quantitative survey conducted by Bell Research on behalf of T-Systems 779 small and medium-sized enterprises were included, in which one of the important findings of the research was that business leaders listed digitization well behind acquiring business and customers, but even improving customer experience and product development lagged behind in terms of importance. Only one in four businesses spent on IT development in the past year, with nearly half of executives surveyed said it was not yet necessary to address the changes caused by the GDPR, and one in three said that IT problems needed to be addressed retrospectively.

According to Reicher [34], the organization-wide project task is to implement a CRM system, as the company's internal stakeholders and IT vendors participate in it together. However, the introduction of a successful CRM system, fundamental changes are triggered in the processes of economic organizations.

Thanks to its intelligent solutions, a CRM system (efficiency-enhancing features and consequent changes) that is in compliance with the potentials of a company's capabilities an enterprise can further increase the competitiveness of familyfriendly workplaces. The retaining of market position in today's fierce competition for customers is essential for corporate survival. 


\section{Research and Methodology}

The aim of our primary research is to examine whether the actors of the SME sector use the potential of the CRM strategy and software solution in order to create a family-friendly environment for the employees. Furthermore, the research aims to explore whether companies strive to:

(1) Offer new types of employee career opportunities so that their employees can successfully manage work-family balance

(2) Take into account the hidden opportunities offered by strategy and software in performance appraisal in workload design.

This research basically consisted of three main parts. First the focus was on the collection of secondary information, in which the focus was placed not only on the national and international literature, but also the regulations concerning companies and the opportunities offered by the state in order to focus on these factors in the analysis was taken into account.

After exploring the secondary information, an in-depth interview with a company manager was conducted. An in-depth interview is a form of qualitative research; it is a direct form of research where the interviewee knows the purpose of the research. It is an advantageous research method when underlying values and beliefs are to be explored [35]. During the interview, answers to the strategic impact of the introduction of a CRM software in the life of a company was looked for. Due to the standard answer options of a questionnaire, many aspects and individual opinions may be lost, thus the underlying reasons and motivations may be hidden, therefore the in-depth interview seemed the most ideal research method to get an idea of the processes, motivation and corporate goals involved in implementing a CRM system in a family-friendly workplace in an SME sector. The qualitative method can provide a good basis for subsequent research based on quantitative methods.

In the quantitative research, family support tools that the state can provide were explored, but companies can also support or create similar support tools. The respondents were asked to assess, considering their own life situation, to what extent, what importance each tool plays in their daily lives, in their career building, and in the management of their families.

The following hypotheses were formulated in respect to the expectations of employees:

H1 1 Employees expect help from their employers in daily childcare and child supervision.

H12 Financial support is important for employees with family, they do not wish to generate extra income with overtime.

H13 Employees with families do not give up career opportunities either, it is also important for them to build a career path. 


\subsection{In-Depth Interview Case Study}

The in-depth interview was conducted with the executive director of the selected company. The interview could be arranged relatively quickly in time. In response to the interviewee's request, anonymity is kept regarding name, company data, industry, number of employees as well as revenue. The interviewee did not give consent to include these data in the paper. The company was selected due to the reason that the executive director had already had a lot of experience in family friendly programs. The in-depth interview took place in April 2020, in the executive's office, which lasted nearly 2 hours. With the consent of the respondent, the interview was recorded to avoid the possibility of distorting writing from memory for later processing. As requested, the audio recording is deleted at the same time this paper is submitted. Open-ended questions were used during the interview, closely related to the topics of the secondary research. In this way, there was an opportunity to get to know the interviewee's position and way of thinking about family-friendly workplaces and the introduction of CRM. The interview started with additional or different warm up questions, so as to create a suitable atmosphere of the interview, dissolve the tension and to tune the process. During the interview, a pleasant atmosphere could be created, which made it easier for the interviewee to open up. A particular attention was put on not to express personal understanding regarding what has been said form the interviewer's side, or just not to contradict the interviewee's opinion, since the goal was to gather information. During the interview, the interviewer tried to act as neutral and partial as possible, thus ruling out the possibility of mistakes that may arise from the problem of inappropriate behavior, given out the long-standing acquaintance of the interviewer and the interviewee.

More and more women and men are face with the dilemma whether the family or work should be placed to the fore in everyday life. It is almost impossible to meet job expectations and family life to the maximum at the same time. This state produces imbalance, which causes tension in the individual, so it brings about more and more conflicts in the corporate organization as well as in family life. However, one of the most important values of the company is the human resource, as his/her knowledge helps the company to develop and remain competitive. As a result, not only to recruit labor force becomes important for companies, but also to retain it, for which traditional jobs may no longer be suitable. Highly qualified employees already expect more from the company in return for the knowledge they have acquired, which may even be aimed at creating a work-life balance was responded by the interviewee to the question what he thinks of today's work life balance issue at workplaces. Consequently, "our company pays special attention to the implementation of family-friendly options. This can be ensured that our company offer various family-friendly solutions to its employees in the form of welfare services so as to ensure work-life balance. We strive to provide an attractive employer background for our colleagues living in family or planning to 
start a family, encouraging good performance and the development of a committed team of professionals".

To the question on how a family-friendly solution can be implemented at their company, the managing director answered the following: "We are committed to our family employees. In addition to a lot of possibilities I highlight the following (because these are the most popular among the employees): we ensure flexible working hours and the associated tools, like working from home, and we ensure that they can bring their children to the workplace". Frey professes the same in his article published in Labor Review [6].

"A short survey was conducted last month among our employees with small children returning from GYES, GYED 1 , to see how our company can express its support to them even more. The result speaks for itself, $85 \%$ of employees would need a nursery at work within the company." said the interviewee. As a father with 3 children, he says from his own experience that the places in public crèches are filled years earlier and that paying for private crèches is not affordable to everyone. He therefore agrees with his subordinates and has already contacted a tender company to apply for the proposal for the realization of a crèche in the workplace announced by the Human Resources Support Manager on behalf of the State Secretariat for Family and Youth Affairs of the Ministry of Human Resources. The company would spend the maximum of HUF 5 million that may be awarded per company in the competition under the fantasy name "Family Friendly Workplace" in opening and running a nursery at the workplace. The Managing Director has not only considered in this decision to reduce the company tax with the amount spent on day care costs, but he expects that such benefits are given to employees that help in keeping workforce for the company and reduce fluctuation. He even believes the child-care services provided within the company does not face and force the employees with the decision to choose between work/career and having children, thus work-life balance becomes more easily accessible.

"The Covid-19 pandemic has dominated the (labor) market as well. Finding and retaining a good professional has become even more prominent in the lives of companies, which results in an increase in the competitiveness of companies. In light of this next to employees with children under 3 years the company wishes to take into account employees raising children of school age" sounded during the interview. Consequently, the company provides school support to such employees as one element of non-wage benefits (called Cafeteria). Although it represents an additional cost to the company in terms of taxation, it is still favorable, as the support given to the beneficiaries in the form of a voucher contributes to reducing the school start-up costs for families in each September.

1 GYES and GYED are childcare benefits and childcare allowances, two forms of family support that allows maternity leave for a parent for up to three years. 
The interviewee emphasized that in addition to moral recognition and the support that can be gained, a winning bid will also bring significant marketing benefits. These items improve the image of the employer, a positive image of the organization is formed in the labor market, which gives extra advantages to a company in the fierce competition for qualified employees.

"The pandemic is also affecting the management of our company, and ownership negotiations are ongoing. Just at a meeting of business owners the company (quasi passing over a paradigm shift with respect to customer relations) decided to introduce a system capable of customer relationship. In our approach we have manifested that we place clients in the focus of our sales activities, their satisfaction related to our services provided are aimed at, the focus is not necessarily to sell our services at any price and by all means. That is, the company focused on retaining its customers in this pandemic situation. We consider the introduction of a CRM system to be an excellent opportunity for this endeavor."

The customer relationship system is going to be implemented as part of a GINOP project. The company possesses the necessary own contribution and also requires external funding from the Growth Loan Program in view of the call for proposals. From the CRM software market, the company chose a suitable software version, which it would run on its own internal server, in island mode for the time being, but providing the opportunity to connect to a later corporate governance system. The software operator has been contacted and the requirements have been assessed, although the application is still in the evaluation stage.

According to the interviewee, they formulated their company's business strategy in such a way that they adapt to the needs, behavior and expectations of their customers by continuously improving their own operations (process, organization, technology). And their CRM strategy is characterized by a "personalized" i.e., sophisticated, tailor-made policy for their customers.

The Managing Director believes that in addition to the family-friendly approach, the introduction of a CRM system will further strengthen their competitive position in the economic market.

\subsection{Research Results}

\subsubsection{Demographic Profile}

In the research, 187 people were questioned exclusively online due to the pandemic situation resulting in a non-random sampling method. The exclusively online form of questioning may distort the composition of the sample; thus no further generalization can be made and no more general conclusions can be drawn from the sample. However, extra attention was paid to the most important aspects for the structure of the database. Although the sample data are far from being representative of any population, a significant proportion of the respondents, 
$73 \%$ are active workers, nearly $10 \%(9.63 \%)$ are on maternity leave (GYES and GYED), and only $18 \%$ are students or unemployed at the time of responding. $60 \%$ of respondents work as subordinates - this is more than $80 \%$ of the $73 \%$ of active workers - so they do not decide on their (work)time, career and benefits. They are the ones most exposed to managerial decisions (Figure 4).

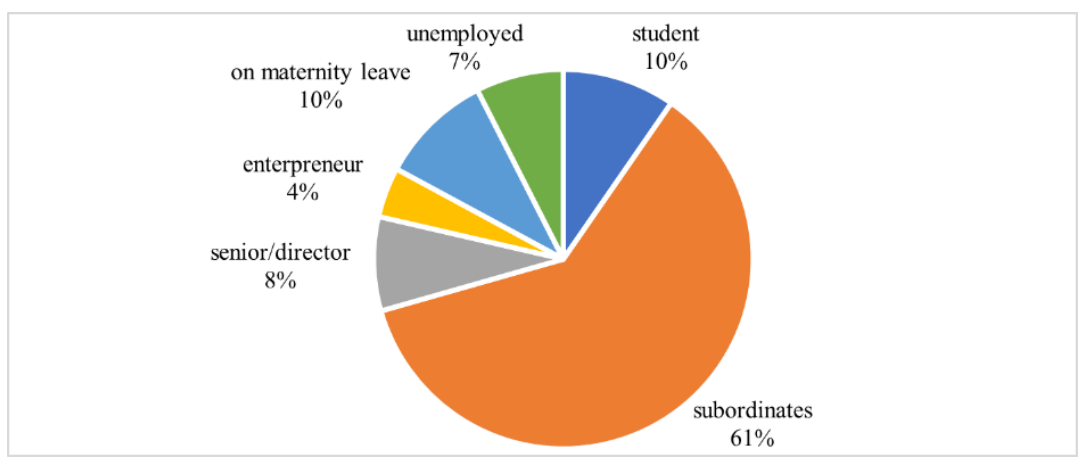

Figure 4

Respondent distribution by mode of employment $(n=187)$

Source: edited by authors

Nearly $60 \%$ of respondents live in a married or cohabiting relationship (40.64\% and $22.46 \%$, respectively) and the same number are raising children $(56.56 \%)$ (Figure 5, Figure 6). According to the gender distribution of our respondents, 57\% are women and $42 \%$ are men. In terms of age distribution, we managed to reach the members of the $\mathrm{Y}$ and $\mathrm{Z}$ generations in large numbers. Half of our respondents came from these two generations. Nearly $70 \%$ of active-age workers responded and filled in the survey. However, it was also considered important to reach the younger generation, as they will also be involved in the labor market in the near future and will come into contact with the topic under discussion. In terms of education, nearly $32 \%$ of respondents have a high school diploma, but $46 \%$ have a college or university degree.

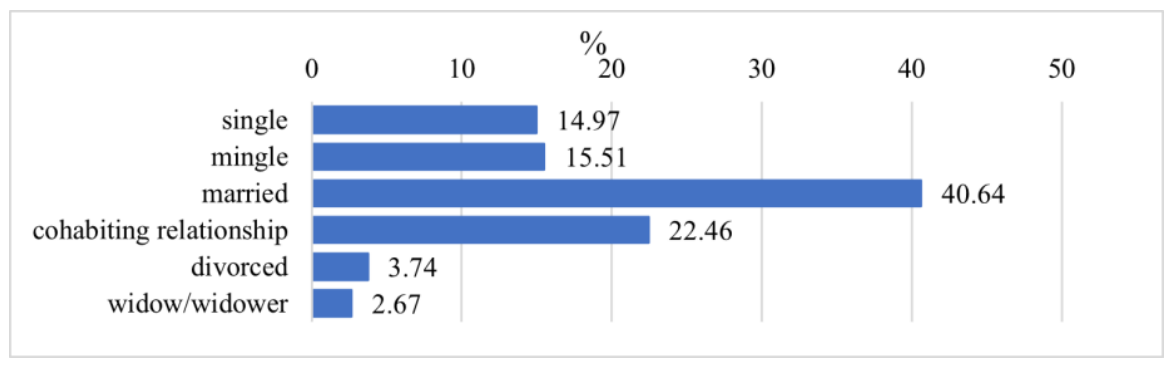

Figure 5

Respondent distribution by form of couple relationship

Source: edited by authors 


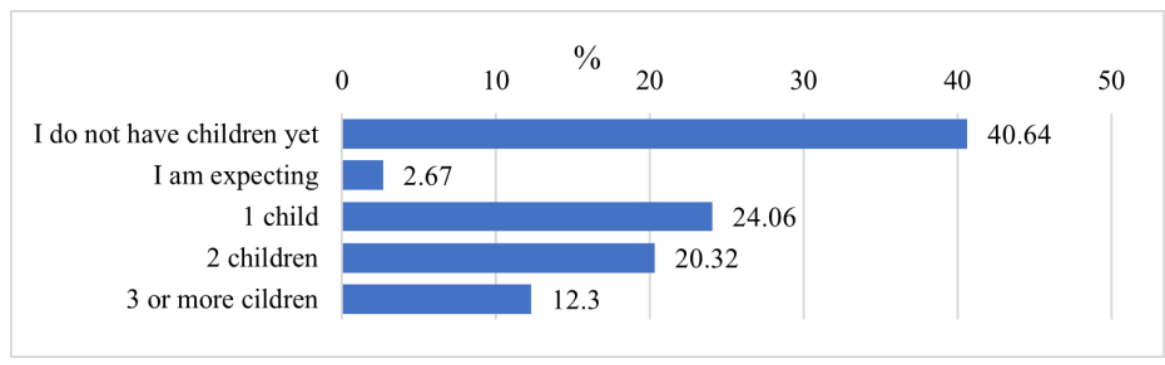

Figure 6

Number of children among the respondents

Source: edited by authors

In terms of industry appearance, the agriculture sector is underrepresented, and the industrial sector is also low in number, but in that sector IT tends to support production, so the chances of a CRM appearing are very low. Nearly $50 \%$ of the respondents came from the areas involved in commerce services, where CRM appears the most.

In terms of territorial distribution, the Central Hungarian region is overrepresented, almost $70 \%$ of the responses came from this region.

\subsubsection{Family Friendly Service Expectations}

The quantitative analyses comprised of a sentiment analysis in which the expectations of employees in relations with daily childcare and support is analyzed. Questions referred to who should help families with young children financially and what kind of services employees with young children expect from the employer (Figure 7).

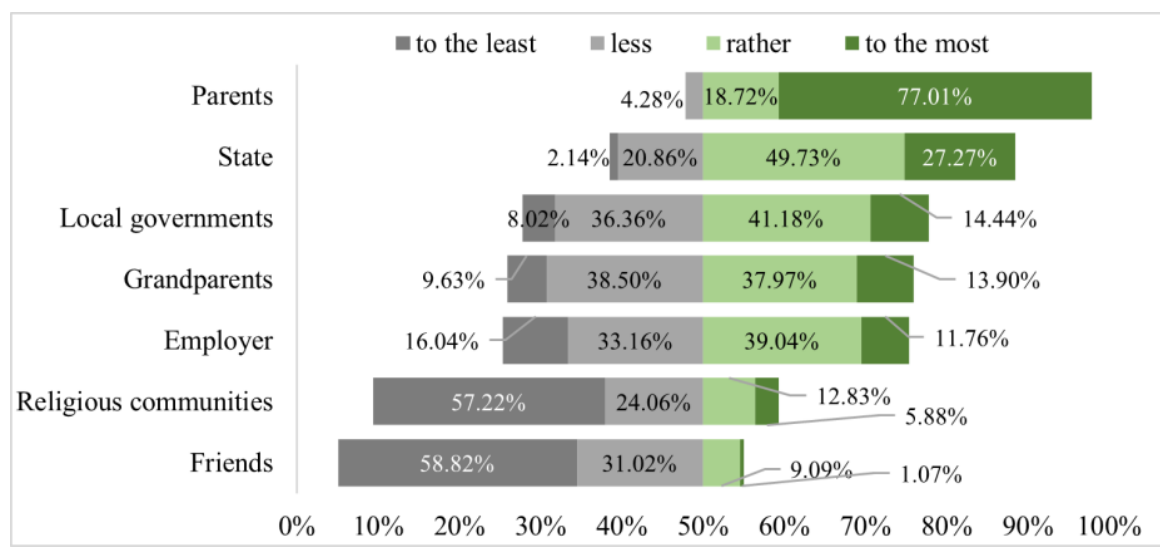

Figure 7

Partners to take part in financial help to families with young children

Source: edited by authors 
The sentiment analysis shows that families still expect the state and the selfgovernment to provide financial help to families with young children while the employer, religious communities and friends are behind grandparents. Based on Figure 7 if the state is in $2^{\text {nd }}$ place and the local government is in $3^{\text {rd }}$ place then it is important to well regulate the role of employer. Nearly $50 \%$ of the respondents say that the employer also has a role in solving financial problems, e.g. school start support, kindergarten, nursery maintenance. This means that the employer, the local community and especially the state plays an important role beyond the parents.

Employees with young children expect childcare, nursery and kindergarten services from the state and the employer. The problems of nursery and kindergarten care found during the qualitative interview appear in the results of the quantitative research as well. It can be seen that those who would rely heavily on the role of the state also expect the employer to help in this area. So, the babymama room also needs to be designed by the employer as the respondents expected. A significant relationship could be detected between these two elements ( $\mathrm{p}=0.043)$, see Figure 8. Consequently, $\mathrm{H} 1_{1}$ is justified.

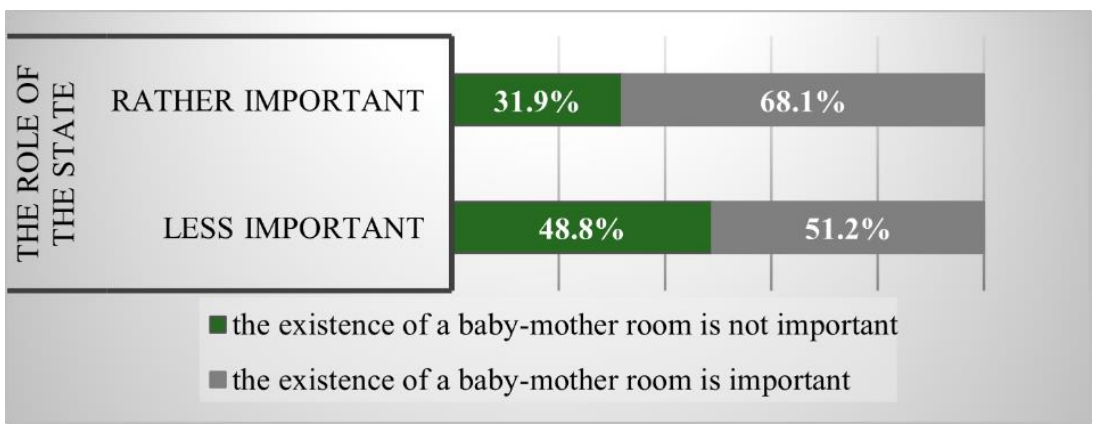

Figure 8

Relation of baby-mama room and state funding Source: edited by authors Source: edited by authors

It was also examined how the imposition of overtime and the expectation of different financial benefits relate to each other. Regarding our respondents, it can be said that for employees with small children who consider it important that the employer does not assign overtime to them it is important significantly $\left(\mathrm{CHI}^{2}=12.756, \mathrm{p}=0.001\right)$ in high proportion that the workplace provides financial benefits beyond the support prescribed by legal regulations. It also suggests that the private and work life balance is highly important for today's worker, but obviously the financial needs do not decrease. Consequently, $\mathrm{H}_{2}$ is also justified.

It was also examined how important it is for respondents to follow an employer's career path. It was found that only $23 \%$ of the active employee age group does not consider it important for their employer to monitor their development and career opportunities. Those who did not consider this important did not show a 
significant difference in their ranks with whom, who supported a career path. The difference for each sector was also examined, but no significant difference appeared in the industry sectors either. However, when education level was considered, it showed that those with tertiary education rated career follow-up significantly $(\mathrm{p}=0.007)$ higher than those with secondary education. Therefore, $\mathrm{H}_{3}$ is not justified.

It can be seen on Figure 9 that ordering overtime is burdensome for employees, and leisure time is valued more by employees with family. However, financial support from other sources would be welcomed to make up for lost income in this way. Nevertheless, a career path is important to them, and they require the employer's attention in this area. A childcare solution is less important to these workers. They search to find other ways to try to solve these problems.

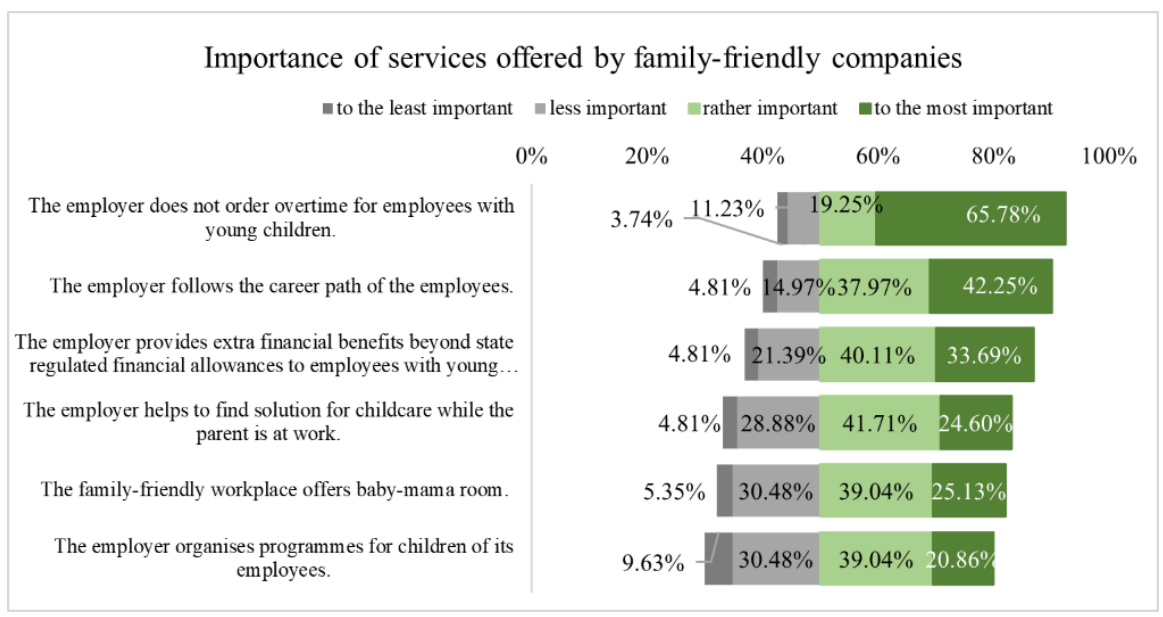

Figure 9

Services offered by family-friendly companies

Source: edited by authors

\section{Conclusions}

The economic weight of SMEs is extremely significant, in the Hungarian economy, so their digital readiness affects the economic competitiveness of the whole country. The direct message from the research is clear, that those who are willing to invest in development, will have a serious advantage over their competitors. The availability of mobile- and tele-working also reveals a great deal about the digital development of businesses: according to the Bell Research study, this is typical for over a third of all businesses (38\%) but it is already over 50\% in the medium-sized business segment. The vast majority of Hungarian SMEs still spend less than $1 \%$ of their sales on infocommunications, even though the services based on these are already necessary for the successful and promising operation of businesses [36]. 
The working habits of the new generation also justify that businesses should be open to new opportunities. The possibility of a home office, part-time work, support for parents with small children are opportunities that can be a serious competitive advantage for the business in the labor market. As a result of structural unemployment, employers face a serious challenge when losing an employee.

In the course of the primary research, an insight could be obtained in the functioning and operation of a "family-friendly" SME and in the initial steps of the introduction of an CRM system. The research has its limitations since specific sectors were included in the research, therefore, the sample could not be considered representative. Due to page limits, only the questions closely related to the literature section were analyzed and strongly indicate that, even in the case of a work-life balance-based company, there is a purpose for customer relationship management, that is, to increase competitiveness. The survey, as exploratory, is only marginally able to draw more generalized conclusions, so additional research is planned, using a larger sample size and focus on economic organizations which are more suitable to quantitatively describe the research area, thus, giving a more comprehensive picture of the subject.

\section{References}

[1] Molennar, C.: e-Marketing - Application of information technology and the internet within marketing, New York: Routledge, 2012

[2] Ternovszky, F.: "Work, women (men), family. Part II. Women-contract work-family," Labor Review, 2005/10, No. 49, 21-23 p.

[3] Heejang, C.: National-level family policies and the access to schedule control in a European comparative perspective: crowding out or in, and for whom?, Journal of Comparative Policy Analysis, 20217. Vol. 21, No. 2, 1$22 \mathrm{p}$.

[4] Kowalewska, H.: Bringing Women on Board: The Social Policy Implications of Gender Diversity in Top Jobs, Journal of Social Policy, 2020, Vol. 49, No. 4, $744-762$ p.

[5] Bencsik, A.; Eisingerné Balassi, B.: The cultural background of intergenerational management and knowledge sharing: "children's rooms" of mosaic families versus coexistence at work, Human Policy Review, 2013, Vol. 20, No. 1-2, 10-25 p.

[6] Frey, M.: Increasing employment by spreading flexible forms of employment, Labor Review, 2010, Vol. III, No. June

[7] Győrpál, T.; Tóth, R.; Kozma, T.: Women 's competencies in running a business, Economics Researchers and Doctoral Students II. Winter Conference, 2015 
[8] Kopp Mária Institute for Population and Families, Report on Family Friendly Tenders 2012-2018, Budapest: Kopp Mária Institute for Population and Families, 2019

[9] Rigby, M.; O’Brien-Smith, F.: Trade union interventions in work-life balance, Work, Employment and Society, 2010, Vol. 24, No. 2, 203-220 p.

[10] Den Dulk, L.; Peters, P.; Poutsma, E.: Variations in adoption of workplace work-family arrangements in Europe: The influence of welfare-state regime and organizational characteristics, International Journal of Human Resource Management, 2012, Vol. 23, No. 13, 2785-2808 p.

[11] European Commission.: Reconciliation between Work, Private and Family Life in the European Union, Luxemburg: European Union, 2009

[12] Fleckenstein, T.; Seeleib-Kaiser, M.: Cross-national perspectives on firmlevel family plicies: Britain, Germany, and the US compared, Converging Worlds of Welfare? British and German Social Policy in the $21^{\text {st }}$ Century, 2011, 129-154 p.

[13] Wiß, T.: Paths towards Family-friendly Working Time Arrangements: Comparing Workplaces in Different Countries and Industries, Social Policy \& Adminstration, 2017, Vol. 51, No. 7, 1406-1430 p.

[14] Ault, J. K.: An institutional perspective on the social outcome of entrepreneurship: Commercial microfinance and inclusive markets, Journal of International Business Studies, 2016, Vol. 47, No. 8, 951-967 p.

[15] Fritsch, M.; Sorgner, A.; Wyrwich, M.: "ypes of institutions and well-being of self-employed and paid employees in Europe, Small Business Economics, 2019, 1-25 p.

[16] Galinsky E.; Johnson, A.: Reforming the Business Case for Work-life Initiatives, 1 ed., New York: Families and Work Institute, 1998

[17] Wood, S.; Daniels, K.; Ogbonnaya, C.: Use of work-nonwork supports and employee well-being: the mediating roles of job demands, job control, supportive management and work-nonwork conflict, International Journal of Human Resource Management, 2018, Vol. 31, No. 14, 1793-1824 p.

[18] Nagy, T.; Dienesné Kovács, E.; Pakurár, M.: Organization of Agricultural Work, Debrecen: University of Debrecen, 2003

[19] Gyenge, B.; Szeghegyi, Á.; Szalay, G.; Kozma, T.: Consumer Control Supportive Visualization, Acta Polytechnica Hungarica, 2021, Vol. 18, No. 10, 65-85 p.

[20] Takács, S.: Objectives of managers and subordinates in performance appraisal: Results of a domestic survey, Management Science, 2001, Vol. 
32, No. 7-12, 31-41 p.

[21] Ma, L.; Ge, C.; Xue, Y.; Tick, A.: Communication problems and solutions faced by Chinese college students entering the workplace, in Proceeding of the $1^{\text {st }}$ GiLE4Youth International Conference, Budapest, 2021, 24-41 p.

[22] Machová, R.; Zsigmond, T.; Lazányi, K.; Krepszová, V.: Generations and Emotional Intelligence, Acta Polytechnica Hungarica, 2020, Vol. 5, No. 17, 229-247 p.

[23] Dajnoki, K.; Fenyves, V.: Exploring fluctuating features through the example of a multinational organization, Human Innovation Review, 2014, Vol. 5, No. 1-2, 6-17 p.

[24] Gyulavári, T.; Agárdi, I.; Bacsek, P.: Exploratory analysis of the domestic practice of CRM, in Marketing network from here and beyond: Study volume of the $21^{\text {st }}$ national conference of the Association for Marketing Education and Research, Magyar, M.; Bíró-Szigeti, S.; Petruska, I.; Szalkai, Z.; Kovács, I. Eds., Budapest, BUTE Department of Management and Business Economics, 2015, 557-586 p.

[25] Révész, B.: The impact of the application of CRM and e-CRM systems on the customer's perception of the company, Marketing and Management, 2005, Vol. 39, No. 1, 42-47 p.

[26] Gandor, D. J.: pm360online.com, 2013. [Online]. Available: https://www.pm360online.com/the-ins-and-outs-of-relationshipmarketing/. [Accessed 12 May 2020]

[27] Payne, A.: CRM Handbook - Advanced Customer Care, Budapest: HVG, 2006

[28] Grönroos, C.: Relationship Marketing: The Strategy Continuum, Journal of the Academy of Marketing Science, 1995, Vol. 23., No. 4, 252-254 p.

[29] Dwyer, F. R.: Developing Buyer-Seller Relationships, The Journal of Marketing, 1987, Vol. 51, No. 2, 11-27 p.

[30] Akunuri, J.: Entrepreneurship marketing - Principles and practice of SME marketing, Oxfordshire: Routledge, 2011

[31] Central Statistical Office (CSO), Characteristics of small and mediumsized enterprises 2018, Budapest: Central Statistics Office, 2018

[32] Jovanović, M.; Šimić, G.; Čabarkapa, M.; Ranđelović, D.; Nikolic, V.; Nedeljković, S.; Čisar, P.: SEFRA - Web-based Framework Customizable for Serbian Language Search Applications, Acta Polytechnica Hungarica, 2019, Vol. 16, No. 3, 59-78 p.

[33] Eurostat, https://ec.europa.eu/eurostat/, 23 September 2021. [Online]. 
Available:

https://ec.europa.eu/eurostat/databrowser/view/tin00116/default/table?lang $=$ en. [Accessed 30 October 2021]

[34] Reicher, R. Z.: Problems of CRM system implementation and selection, in Business development in the 21 st century, Csiszárik-Kocsir, Á. Ed., Budapest, Óbuda University, 2017, 514-527 p.

[35] Malhotra, N. K.: Marketing Research, 3rd ed., New York: Pearson Education, 2009

[36] Bell Research Research, Analyst and Consulting Ltd., Hungarian Infocommunication Report, Bell research, 2020 